\title{
Using AHP and the IPMA Competence Baseline in the project managers selection process
}

\author{
João Varajão ${ }^{\mathrm{a}, \mathrm{b}}$ and Maria Manuela Cruz-Cunha ${ }^{\mathrm{c}, \mathrm{d} *}$ \\ ${ }^{a}$ Department of Engineering, University of Trás-os-Montes e Alto Douro, Vila Real, Portugal; ${ }^{b}$ Algoritmi Research Center, University \\ of Minho, Guimarães, Portugal; ${ }^{c}$ Department of Technology, Polytechnic Institute of Cávado and Ave, Barcelos, Portugal; ${ }^{d}$ CGIT \\ Research Center, University of Minho, Guimarães, Portugal
}

(Received 6 February 2012; final version received 27 January 2013)

\begin{abstract}
This paper proposes the joint use of the AHP (Analytic Hierarchy Process) and the ICB (IPMA Competence Baseline), as a tool for the decision-making process of selecting the most suitable managers for projects. A hierarchical structure, comprising the IPMA's ICB 3.0 contextual, behavioural and technical competence elements, is constructed for the selection of project managers. It also describes the AHP implementation, illustrating the whole process with an example using all the 46 ICB competence elements as model criteria. This tool can be of high interest to decision-makers because it allows comparing the candidates for managing a project using a systematic and rigorous process with a rich set of proven criteria.
\end{abstract}

Keywords: project manager; project management; multi criteria decision making; AHP; IPMA Competence Baseline; IPMA

\section{Introduction}

Project management is the application of knowledge, skills, tools and techniques to project activities to meet the project requirements (PMI 2008). In other words, it comprehends the planning, delegation, monitoring and control of all aspects of a project, and it sustains the motivation of the various factors involved, in order to achieve the goals set for the project, accomplishing the expected performance in terms of time, cost, quality, scope, benefits and risk (OGC 2009).

Today, at the dawn of the twenty-first century, the knowledge and understanding of project management has matured and organisations recognise the importance of project management for business development. This is supported by several standards available in this domain such as, for instance, the ICB (IPMA competence baseline) (IPMA 2006) of the International Project Management Association, the PMBoK (Project Management Book of Knowledge) (PMI 2008) of the Project Management Institute, or the PRINCE2 (PRojects IN a Controlled Environment) of the Office of Government Commerce (OGC 2009), which are currently adopted by organisations all over the world (Fisher 2010).

Project management standards are increasingly been regarded as an important building block in modern organisations. They are expected to help harmonise divergent terminology and different understandings of processes and methods (Ahlemann, Teuteberg, and Vogelsang 2009). Nevertheless, despite the attention that in recent years has been devoted to project management, in many cases the projects are still not providing the desired success. The software development projects are one of the paradigmatic cases, with several studies (for example, Varajão et al. 2008; Standish Group 2010) revealing serious deviations in terms of time, cost or scope. It is an important part of the mission of the project management to minimise these failures, and to develop projects with maximum efficiency and effectiveness.

Project management is nowadays essential in the context of the development of successful projects, being transversal and having applications in many industries, as in the case of software engineering, manufacturing, construction, aeronautics, among others. This is particularly true in large projects, where the need for a competent project management structure becomes more evident and truly indubitable due to the complexity involved.

In fact, with the increasing complexity of organisations, requiring more complex and extended projects to meet their needs, the selection of well-trained managers ready for the leadership of the projects is a critical success factor. Employing a poorly prepared project manager, without the necessary knowledge and experience, is something that could jeopardise the success of the project (Pinto and Slevin 1987; Möller and Turner 2007a), given that she or he will probably not be able to properly manage the project in all its dimensions: scope, time, cost, quality, risk, communication, procurement, human resources and integration.

*Corresponding author. Email: mcunha@ipca.pt 
As more organisations adopt project management as a modus operandi to deliver work packages, and the demand for project managers grows, there is an increasing interest in the personal skills of project managers and in standards for development and assessment of project management competence (Fisher 2010). But selecting the most qualified project managers can be a huge endeavour, due to the multiple aspects that should be considered, some of them of a subjective nature.

Due to the importance of selecting the 'right' project managers for projects, decision tools are needed to support and assure a rigorous selection process. Multi criteria decision making techniques, namely AHP, have been noticeably utilised for solving the problem of personnel selection, based on competency criteria hierarchies (Gilan, Sebt, and Shahhosseini 2012). To help in the selection of the most suitable project managers, this paper proposes the joint use of AHP (Analytic Hierarchy Process) and ICB (IPMA Competence Baseline), focusing the selection criteria on the knowledge and experience of the potential candidates.

AHP is a decision-aiding multi-criteria technique proposed by Saaty (1980), which has been widely used in many different contexts of project management, as discussed later in the paper. The ICB is proposed by IPMA (International Project Management Association) and it provides a definition of the competences expected from project management personnel (IPMA 2006).

While it is well known the application of AHP to multi criteria decision making and to selection processes, the proposed combination of AHP with ICB is new, and the authors were not able to find in literature other approaches similar to the one proposed in this paper.

The paper is organised as follows. The next section introduces the ICB and Section 3 makes a description of AHP technique. Section 4 presents the AHP hierarchical structure and the criteria for project manager's selection following ICB. The AHP implementation using ICB is discussed in Section 5 and the paper concludes with some final remarks in Section 6.

\section{IPMA competence baseline}

The IPMA Competence Baseline (ICB) is the common framework document that all IPMA member associations and certification bodies abide by to ensure that consistent and harmonised standards are applied. As such, the majority of its content focuses on the description of the competence elements (IPMA 2006).

Competence in the context of ICB is the confirmed ability to apply knowledge and/or skills, and, where relevant, proved personal attributes. A competence is a collection of knowledge, personal attitudes, skills and relevant experience needed to be successful in a certain function.

To help candidates measure and develop themselves and to help assessors judging a candidate's competence, the ICB splits competence down into ranges. The ranges are mainly dimensions that together describe the function and are more or less independent. Each range contains competence elements that cover the most important competence aspects in that particular range (IPMA 2006):

- The technical competence range - to describe the fundamental project management competence elements. This range covers the project management content, sometimes referred to as the solid elements. The ICB contains 20 technical competence elements;

- The behavioural competence range - to describe the personal project management competence elements. This range covers the project manager's attitudes and skills. The ICB contains 15 behavioural competence elements;

- The contextual competence range - to describe the project management competence elements related to the context of the project. This range covers the project manager's competence in managing relations with the line management organisation and the ability to function in a project focused organisation. The ICB contains 11 contextual competence elements.

For assessment purposes, the ICB defines taxonomy of competence graded along a scale from 0 through 10 for knowledge as well as for experience. This is graded for each competence element as follows:

- 0 means that a candidate has no knowledge and/or experience:

- Knowledge: none.

- Experience: none.

- 1 to 3 means that a candidate has a low level of knowledge and/or experience:

- Knowledge: The candidate knows the element and is able to present and explain known criteria for this element.

- Experience: The candidate has some experience obtained from a project management role in a few projects, set into one sector of the economy or unit of an organisation during one or several phases of these projects. 
- Description: Some experience, from being involved as an assistant, in some phases, of a few projects, with a good awareness of project management.

- 4 to 6 means that a candidate has a medium level of knowledge and/or experience:

- Knowledge: The candidate has a solid level of knowledge and is able to recognise and to apply the relevant criteria as well as check the results.

- Experience: The candidate has an average level of experience and an average record which he obtained from many important project management areas of several projects in at least one important sector of the economy during most phases of these projects.

- Description: Considerable experience, in a responsible project management position, in most phases, of several different projects, with limited complexity, with a good awareness of project management.

- 7 to 9 means that a candidate has a high level of knowledge and/or experience:

- Knowledge: The candidate understands the role in detail and is able to evaluate, to create and to integrate the relevant criteria, and can interpret and evaluate the results.

- Experience: The candidate has a broad range of experience and a good track record which he has gained from responsible project management roles in many different kinds of projects, during most or all phases of these projects.

- Description: Extensive experience in project management positions with a high level of responsibility, in most phases, of several different projects and/or programmes or portfolios, with a thorough understanding of project management.

- 10 means that a candidate has exceptional knowledge and/or experience:

- Knowledge: Absolute maximum.

- Experience: Absolute maximum.

Knowledge does not mean solely the correct reproduction of the facts, but also understanding relationships, knowing how to apply project management in practical situations and to interpret methods. The evidence demonstrating that the individual has the required level of knowledge is normally provided by answering questions. The project manager does not gain much experience from doing the same type of project for many years. He should apply the knowledge in real and different situations (e.g. projects of different sizes, different kinds of projects, different organisations, branches of the organisation and/or cultures).

As stated by IPMA (IPMA 2006), the ICB should be of best use to individuals and assessors when undertaking an assessment. However, it can also be used as a guide for the preparation of training materials, for research purposes and as a general reference document for people seeking information about applied project management. In addition it is a good basis for planning professional development. In this work, ICB is used as basis for selecting managers for projects.

It is important to note that the performance of a project manager will depend intrinsically on whether s/he can implement the managerial practices effectively and efficiently (Chen and Lee 2007).

\section{Analytic hierarchy process}

Among the various multi criteria decision making techniques discussed in literature, the Analytic Hierarchy Process (AHP) proposed by Saaty (1980) has been applied in a wide variety of areas including planning, selecting a best alternative, resource allocation and resolving conflicts (Carazo et al. 2010; Gutjahr et al. 2010; Ho, Xu, and Dey 2010; Yang and Chou 2011; Felice 2012; Larrodé, Moreno-Jiménez, and Muerza 2012).

AHP is a technique for dealing with complex decisions (Saaty 1980; Bertolini, Braglia, and Carmignani 2006), where: Analytic indicates that the problem is broken down into its constitutive elements; Hierarchy indicates that a hierarchy of the constitutive elements is listed in relation to the main goal; Process indicates that data and judgments are processed to reach the final result. The main idea is to decompose the decision problem into a hierarchy of more easily comprehended sub-problems.

One of the main aspects of AHP is that it can be used to establish measures in both the physical and social domains. As a general theory for measurement, it can be used to derive relative priorities on absolute scales in multilevel hierarchic structures (Saaty and Vargas 2006).

AHP helps decision-makers to select a solution from a set of alternatives, by enabling a systematic comparison of the alternatives. It has been widely used in many different contexts in project management (Kwak and Anbari 2009), from selecting contractors in project management (Al-Harbi 2001) to evaluation of project termination (Wen-Yau 2003). Subramanian and Ramanathan (2012) make a very complete review on the applications of AHP in manufacturing 


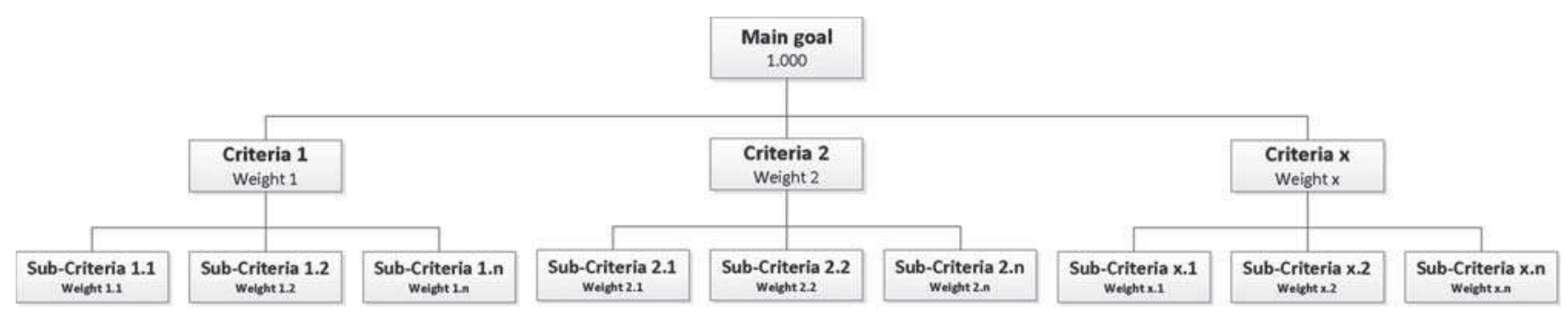

Figure 1. AHP sample hierarchical structure.

operations and processes, based on relevant literature, namely product and process design and managing the supply chain, including the wide application of AHP to macro and people oriented problems. The application to project managers selection is discussed in several papers (Zavadskas et al. 2012), as well has been applied to recruitment (Hsiao et al. 2011), to managers selection (Kelemenis, Ergazakis, and Askounis 2011).

The AHP is constituted of three main moments:

- Definition of the problem and main goal;

- The definition of a hierarchy tree of criteria, with a weight definition for each criteria;

- The evaluation of alternative solutions, using the defined tree.

The hierarchy tree is structured from top (the main goal from the viewpoint of the decision-maker), through the criteria, to the sub-criteria, and so on. The tree can have as many levels as needed. Figure 1 presents a sample hierarchical structure with three levels. At the top is the main goal. At the second level, we find 'Criteria 1', 'Criteria 2' and 'Criteria $x$, each one with a specific weight for the decision. The sum of Weight 1, Weight 2 and Weight $n$, should be 1.000. Each of these criteria is characterised by a set of sub-criteria. For instance, Criteria 1 is characterised by Sub-Criteria 1.1, Sub-criteria 1.2 and Sub-criteria 1.n. The sum of the weights of the sub-criteria should also be 1.000 .

Later on the process, each alternative solution will be evaluated using the defined sub-criteria (the criteria on the lower level) and the calculations will be made by using the defined weights; i.e. the hierarchy tree is the decision model that will be used to identify the best solution in the context of the decision problem.

The evaluation of the different alternatives follows the process proposed by Saaty $(1980,1990)$ :

- Develop a set of pair-wise comparison matrices, establishing priorities among the alternatives (the matrices will have a size of $n \times n$, where $n$ is the number of alternative solutions). This is done by making a series of judgments between the alternative solutions, using a pre-defined scale (an example is described in Table 2);

- Synthesise the judgments to obtain the overall priorities for the hierarchy;

- Check the consistency of the judgments, by calculating the consistency index (CI), identifying the correspondent value of random consistency ratio (RI) which is determined by the size of the matrix (see Table 5), and calculating the consistency ratio (CR), which is acceptable if it does not exceed 0.10 . If $\mathrm{CR}$ is higher than 0.10 , then the judgment matrix is inconsistent and judgments should be reviewed and improved;

- Come to a final decision based on the results obtained.

All steps of this process are described and exemplified in detail in Sections 4 and 5.

Due to the high number of aspects/criteria that should be taken into account when selecting a manager for a specific project, the AHP approach can be a major utility to decision-makers because it enables a rigorous selection process.

\section{Hierarchical structure and criteria for project managers selection}

As stated in the previous section, an important phase of AHP is the definition of the hierarchy tree. Starting from the main goal (the first level of the hierarchy), then to the definition of the criteria and sub-criteria, each sublevel characterising $100 \%$ the upper level.

In this work, the main goal is the 'selection of the most suitable project manager' for specific projects. Following ICB, we propose that this selection should be based on the knowledge and experience of the project managers, as it is done in the IPMA certification process. So, 'knowledge' and 'experience' will be the main criteria to select the project 
managers, being at the second level of the hierarchy. The sub-criteria for knowledge and experience will be the ICB competence elements.

ICB proposes three types of competence elements (IPMA 2006): technical; behavioural; and contextual.

Technical competence elements are needed to initiate and to start, to manage the execution of, and to close a project. They include: 1.01 Project management success; 1.02 Interested parties; 1.03 Project requirements and objectives; 1.04 Risk and opportunity; 1.05 Quality; 1.06 Project organisation; 1.07 Teamwork; 1.08 Problem resolution; 1.09 Project structures; 1.10 Scope and deliverables; 1.11 Time and project phases; 1.12 Resources; 1.13 Cost and finance; 1.14 Procurement and contract; 1.15 Changes; 1.16 Control and reports; 1.17 Information and documentation; 1.18 Communication; 1.19 Start-up; 1.20 Close-out.

Behavioural competence elements include personal project management competences, covering the project manager's attitudes and skills. These competences are: 2.01 Leadership; 2.02 Engagement and motivation; 2.03 Self-control; 2.04 Assertiveness; 2.05 Relaxation; 2.06 Openness; 2.07 Creativity; 2.08 Results orientation; 2.09 Efficiency; 2.10 Consultation; 2.11 Negotiation; 2.12 Conflict and crisis; 2.13 Reliability; 2.14 Values appreciation; 2.15 Ethics.

Finally, contextual competence elements describe the concepts of project, programme and portfolio and the linkage between these concepts and the organisation or organisations that are involved in the project. Include: 3.01 Project orientation; 3.02 Programme orientation; 3.03 Portfolio orientation; 3.04 PPP implementation; 3.05 Permanent organisation; 3.06 Business; 3.07 Systems, products and technology; 3.08 Personnel management; 3.09 Health, security, safety and environment; 3.10 Finance; 3.11 Legal.

The complete hierarchical structure is represented in Figure 2. This structure establishes the model that will be used to evaluate and compare the candidates for a project manager for a manufacturing (or other) project.

\section{AHP implementation using IPMA competence baseline}

To illustrate the AHP implementation using the IPMA competence baseline, this section presents a complete example, considering three candidates (PM A - Project Manager A; PM B - Project Manager B; and PM C - Project Manager C) for managing a new project.

The individual scores of the project manager candidates were randomly assigned for simulation purposes, and are represented in Table 1, using a scale from 0 (no competence) to 10 (absolute maximum); this scale is the same proposed by IPMA to access project managers (IPMA 2006). The first column of the table identifies the competence type, the second column lists all the competences, the third column has the competence weights for the knowledge criteria and the forth column defines the competence weights for the experience criteria. The remaining columns have the scores of knowledge and experience for Project Manager A, Project Manager B and Project Manager C.

By convenience, we defined equal weights to all the competences, according to their type (the weighting factors applied are based on the percentage distributions between the three competence ranges). However, it is important to note that the relevance of each competence element can and will differ depending on the situation. In other words, the importance or weight of a competence is dependent upon the specific project situation (IPMA 2006). To achieve success, different projects may require different approaches to their management, and also that both the project management procedures used (Crawford, Hobbs, and Turner 2005; Papke-Shields, Beise, and Quan 2010), and the project manager's competence should be selected to meet the needs of the particular type of project (Müller and Turner 2007b; Fisher 2010; Müller and Turner 2010). So, the decision-maker when using this tool should define the weights according to the particular project characteristics and needs.

To identify the 'best candidate', following the AHP procedure explained in Section 3 and the hierarchy presented in Section 4, it is required to (Al-Harbi 2001):

(1) Indicate preferences for each decision alternative in terms of how it contributes to each criterion, creating pair-wise comparison matrices;

(2) Synthesise the pair-wise comparison matrices;

(3) Compute the priority vector for the criterion;

(4) Compute the consistency ratio;

(5) Check the consistency of the pair-wise comparison matrices to check whether the decision-maker comparison is consistent;

(6) Compute final scores for each candidate. 


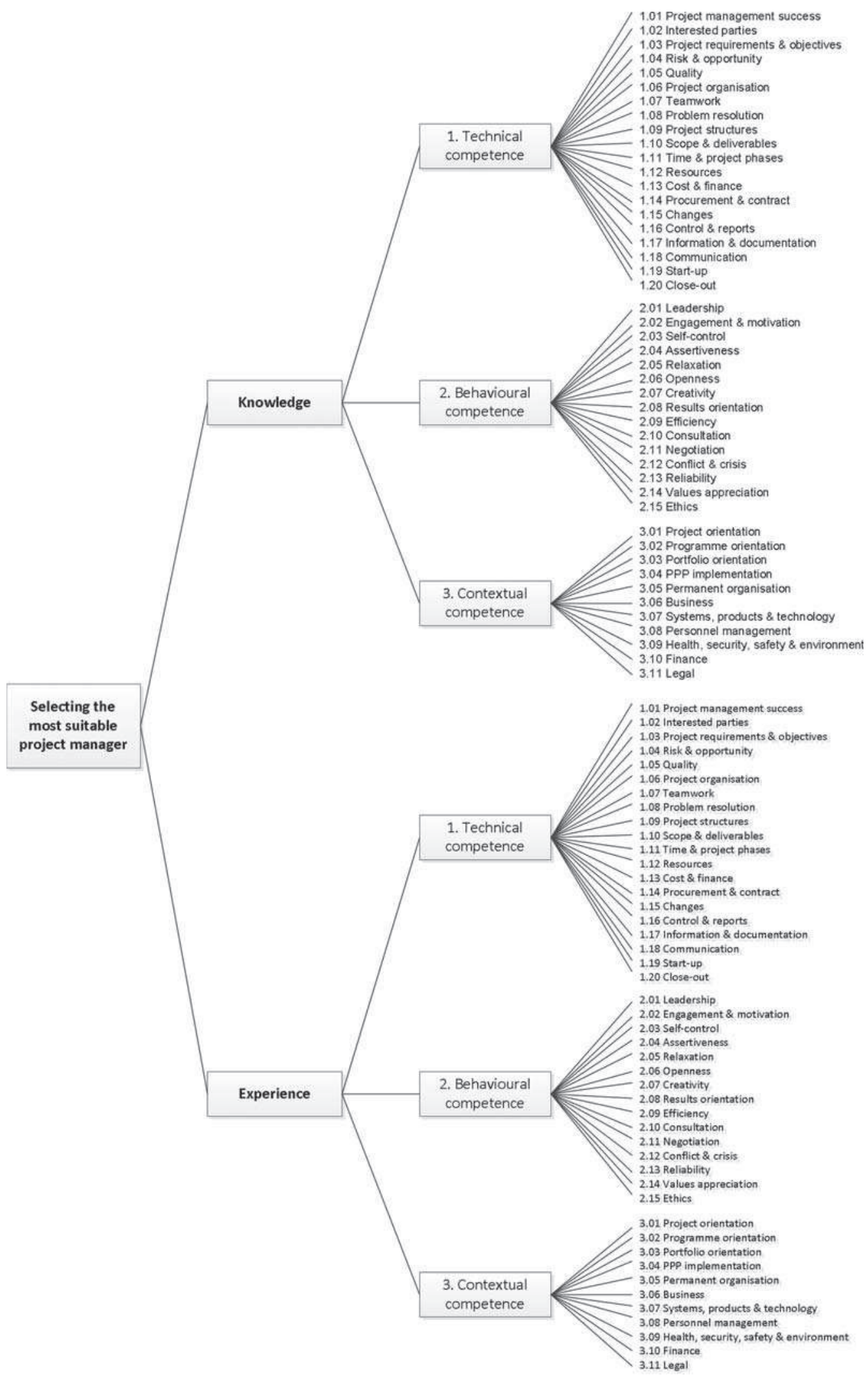

Figure 2. Hierarchical structure. 
Table 1. Candidate project managers (example).

\begin{tabular}{|c|c|c|c|c|c|c|c|c|c|}
\hline \multirow[b]{2}{*}{ Project managers } & & \multirow[b]{2}{*}{ WK } & \multirow[b]{2}{*}{ WE } & \multicolumn{2}{|c|}{ Project Manager A } & \multicolumn{2}{|c|}{ Project Manager B } & \multicolumn{2}{|c|}{ Project Manager C } \\
\hline & & & & Knowledge & Experience & Knowledge & Experience & Knowledge & Experience \\
\hline \multirow[t]{20}{*}{$\begin{array}{l}\text { Technical } \\
\text { competences }\end{array}$} & $\begin{array}{l}1.01 \text { Project } \\
\text { management success }\end{array}$ & 0.05 & 0.05 & 1 & 5 & 3 & 4 & 5 & 3 \\
\hline & 1.02 Interested parties & 0.05 & 0.05 & 4 & 6 & 6 & 7 & 6 & 6 \\
\hline & $\begin{array}{l}1.03 \text { Project } \\
\text { requirements and } \\
\text { objectives }\end{array}$ & 0.05 & 0.05 & 1 & 2 & 4 & 7 & 2 & 4 \\
\hline & $\begin{array}{l}1.04 \text { Risk and } \\
\text { opportunity }\end{array}$ & 0.05 & 0.05 & 3 & 3 & 6 & 4 & 3 & 6 \\
\hline & 1.05 Quality & 0.05 & 0.05 & 7 & 4 & 4 & 4 & 4 & 4 \\
\hline & $\begin{array}{l}\text { 1.06 Project } \\
\text { organisation }\end{array}$ & 0.05 & 0.05 & 7 & 4 & 8 & 8 & 4 & 8 \\
\hline & 1.07 Teamwork & 0.05 & 0.05 & 6 & 3 & 7 & 7 & 3 & 7 \\
\hline & $\begin{array}{l}1.08 \text { Problem } \\
\text { resolution }\end{array}$ & 0.05 & 0.05 & 8 & 5 & 4 & 6 & 5 & 4 \\
\hline & 1.09 Project structures & 0.05 & 0.05 & 6 & 5 & 5 & 7 & 5 & 5 \\
\hline & $\begin{array}{l}1.10 \text { Scope and } \\
\text { deliverables }\end{array}$ & 0.05 & 0.05 & 4 & 4 & 6 & 7 & 4 & 6 \\
\hline & $\begin{array}{l}1.11 \text { Time and project } \\
\text { phases }\end{array}$ & 0.05 & 0.05 & 5 & 2 & 4 & 6 & 2 & 4 \\
\hline & 1.12 Resources & 0.05 & 0.05 & 6 & 4 & 5 & 8 & 4 & 5 \\
\hline & 1.13 Cost and finance & 0.05 & 0.05 & 2 & 2 & 6 & 7 & 2 & 6 \\
\hline & $\begin{array}{l}1.14 \text { Procurement and } \\
\text { contract }\end{array}$ & 0.05 & 0.05 & 3 & 3 & 5 & 8 & 3 & 5 \\
\hline & 1.15 Changes & 0.05 & 0.05 & 4 & 3 & 5 & 6 & 3 & 5 \\
\hline & $\begin{array}{l}1.16 \text { Control and } \\
\text { reports }\end{array}$ & 0.05 & 0.05 & 8 & 6 & 5 & 4 & 6 & 5 \\
\hline & $\begin{array}{l}\text { 1.17 Information and } \\
\text { documentation }\end{array}$ & 0.05 & 0.05 & 6 & 6 & 3 & 3 & 6 & 3 \\
\hline & 1.18 Communication & 0.05 & 0.05 & 8 & 8 & 5 & 3 & 8 & 5 \\
\hline & 1.19 Start-up & 0.05 & 0.05 & 7 & 7 & 3 & 6 & 7 & 3 \\
\hline & 1.20 Close-out & 0.05 & 0.05 & 6 & 6 & 3 & 6 & 6 & 3 \\
\hline \multirow{15}{*}{$\begin{array}{l}\text { Behavioural } \\
\text { competences }\end{array}$} & 2.01 Leadership & 0.07 & 0.07 & 8 & 7 & 3 & 3 & 7 & 3 \\
\hline & $\begin{array}{l}2.02 \text { Engagement and } \\
\text { motivation }\end{array}$ & 0.07 & 0.07 & 6 & 9 & 3 & 2 & 9 & 3 \\
\hline & 2.03 Self-control & 0.07 & 0.07 & 8 & 8 & 4 & 3 & 8 & 4 \\
\hline & 2.04 Assertiveness & 0.07 & 0.07 & 7 & 9 & 3 & 3 & 9 & 3 \\
\hline & 2.05 Relaxation & 0.07 & 0.07 & 7 & 7 & 2 & 1 & 7 & 2 \\
\hline & 2.06 Openness & 0.07 & 0.07 & 4 & 5 & 8 & 6 & 5 & 8 \\
\hline & 2.07 Creativity & 0.07 & 0.07 & 4 & 6 & 7 & 5 & 6 & 7 \\
\hline & $\begin{array}{l}2.08 \text { Results } \\
\text { orientation }\end{array}$ & 0.07 & 0.07 & 1 & 3 & 7 & 7 & 3 & 7 \\
\hline & 2.09 Efficiency & 0.07 & 0.07 & 4 & 4 & 6 & 6 & 4 & 6 \\
\hline & 2.10 Consultation & 0.07 & 0.07 & 5 & 4 & 7 & 6 & 4 & 7 \\
\hline & 2.11 Negotiation & 0.07 & 0.07 & 2 & 5 & 8 & 7 & 5 & 8 \\
\hline & $\begin{array}{l}2.12 \text { Conflict and } \\
\text { crisis }\end{array}$ & 0.07 & 0.07 & 8 & 8 & 7 & 6 & 8 & 7 \\
\hline & 2.13 Reliability & 0.07 & 0.07 & 7 & 7 & 8 & 7 & 7 & 7 \\
\hline & $\begin{array}{l}2.14 \text { Values } \\
\text { appreciation }\end{array}$ & 0.07 & 0.07 & 4 & 8 & 7 & 6 & 8 & 7 \\
\hline & 2.15 Ethics & 0.07 & 0.07 & 8 & 8 & 8 & 8 & 8 & 8 \\
\hline \multirow[t]{4}{*}{$\begin{array}{l}\text { Contextual } \\
\text { competences }\end{array}$} & $\begin{array}{l}3.01 \text { Project } \\
\text { orientation }\end{array}$ & 0.09 & 0.09 & 6 & 5 & 8 & 6 & 5 & 8 \\
\hline & $\begin{array}{l}3.02 \text { Programme } \\
\text { orientation }\end{array}$ & 0.09 & 0.09 & 5 & 3 & 9 & 3 & 3 & 8 \\
\hline & $\begin{array}{l}3.03 \text { Portfolio } \\
\text { orientation }\end{array}$ & 0.09 & 0.09 & 3 & 3 & 6 & 3 & 3 & 5 \\
\hline & $\begin{array}{l}3.04 \text { PPP } \\
\text { implementation }\end{array}$ & 0.09 & 0.09 & 4 & 3 & 4 & 3 & 3 & 6 \\
\hline
\end{tabular}


Table 1. (Continued).

\begin{tabular}{|c|c|c|c|c|c|c|c|c|c|}
\hline \multirow{2}{*}{\multicolumn{2}{|c|}{ Project managers }} & \multirow[b]{2}{*}{ WK } & \multirow[b]{2}{*}{ WE } & \multicolumn{2}{|c|}{ Project Manager A } & \multicolumn{2}{|c|}{ Project Manager B } & \multicolumn{2}{|c|}{ Project Manager C } \\
\hline & & & & Knowledge & Experience & Knowledge & Experience & Knowledge & Experience \\
\hline & $\begin{array}{l}3.05 \text { Permanent } \\
\text { organisation }\end{array}$ & 0.09 & 0.09 & 6 & 9 & 5 & 6 & 9 & 5 \\
\hline & 3.06 Business & 0.09 & 0.09 & 7 & 8 & 5 & 5 & 8 & 5 \\
\hline & $\begin{array}{l}3.07 \text { Systems, } \\
\text { products and } \\
\text { technology }\end{array}$ & 0.09 & 0.09 & 7 & 8 & 7 & 6 & 8 & 4 \\
\hline & $\begin{array}{l}3.08 \text { Personnel } \\
\text { management }\end{array}$ & 0.09 & 0.09 & 5 & 7 & 7 & 7 & 7 & 7 \\
\hline & $\begin{array}{l}3.09 \text { Health, security, } \\
\text { safety and } \\
\text { environment }\end{array}$ & 0.09 & 0.09 & 8 & 7 & 5 & 5 & 7 & 5 \\
\hline & 3.10 Finance & 0.09 & 0.09 & 7 & 6 & 4 & 6 & 6 & 8 \\
\hline & 3.11 Legal & 0.09 & 0.09 & 7 & 5 & 5 & 6 & 5 & 5 \\
\hline
\end{tabular}

These steps will be explained in the subsequent paragraphs. Since this process can be arduous, it is recommend the use of an AHP software tool. In our case it was created as a spread sheet that automated the process.

\subsection{Indication of preferences for each decision alternative}

For each decision, the decision-maker has to indicate the preferences or priority of each decision alternative in terms of how it contributes to each criterion. Table 2 reports the scale that will be used in this example, adapted from the scheme proposed by Saaty (Saaty 1980; Bertolini, Braglia, and Carmignani 2006). In the second column (difference on classification), we can find the criteria for selecting the scores for the decision alternatives.

Table 3 reports some of the pair-wise comparison matrices needed. Specifically, it reports the matrices for competences $1.01,1.02,1.03,1.04$ (for the knowledge criteria).

The matrix for competence 1.01 is obtained by:

(1) Listing the candidates (PM A, PM B, PM C) as rows and columns headers;

(2) Compare each pair of candidates regarding competence 1.01 (Project management success) and fill the matrix cells:

(a) Cell PM A - PM A: in this case, we are comparing PM A with himself, so obviously there are no differences to state. Considering Table 2, the score is 1 (judgment 'Equal');

(b) Cell PM A - PM B: considering Table 1, PM A has a classification of 1 for the competence 1.01/knowledge and PM B has a classification of 3 . So, the difference in the classifications is 2 (3-1), favourable to PM B. Considering Table 2, the score is 3 for a difference of 2 in classification (judgment 'Weakly better'). So we should fill the cell with the value $1 / 3(0.33)$;

(c) Cell PM A - PM C: considering Table 1, PM A has a classification of 1 for the competence 1.01/knowledge and $\mathrm{PM} \mathrm{C}$ has a classification of 5 . So, the difference in the classifications is 4 (5-1), favourable to PM C. Considering Table 2, the score is 5 (judgment 'Definitely better'). So we should fill the cell with the value $1 / 5(0.20)$;

(d) Cell PM B - PM A: considering Table 1, PM B has a classification of 3 for the competence 1.01/knowledge and PM A has a classification of 1 . So, the difference in the classifications is 2 (3-1), favourable to PM B. Considering

Table 2. Pair-wise comparison scale for AHP preferences.

\begin{tabular}{lcc}
\hline Judgment & Difference on classification \\
\hline Equal & 0 & Score \\
Barely better & 1 & 2 \\
Weakly better & 2 & 3 \\
Moderately better & 3 & 5 \\
Definitely better & 4 & 5 \\
Strongly better & 5 & 7 \\
Very strongly better & 6 \\
Critically better & 7 \\
Absolutely better & $>=8$ \\
\hline
\end{tabular}


Table 3. Pair-wise comparison matrix for competences 1.01, 1.02, 1.03, 1.04 (knowledge criteria).

\begin{tabular}{|c|c|c|c|}
\hline 1.01 & PM A & PM B & PM C \\
\hline PM A & 1 & 0.33 & 0.20 \\
\hline PM B & 3.00 & 1 & 0.33 \\
\hline PM C & 5.00 & 3.00 & 1 \\
\hline 1.03 & PM A & PM B & PM C \\
\hline PM A & 1 & 0.25 & 0.50 \\
\hline PM B & 4.00 & 1 & 3.00 \\
\hline PM C & 2.00 & 0.33 & 1 \\
\hline
\end{tabular}

\begin{tabular}{llll}
\hline 1.02 & PM A & PM B & PM C \\
\hline PM A & 1 & 0.33 & 0.33 \\
PM B & 3.00 & 1 & 1.00 \\
PM C & 3.00 & 1.00 & 1 \\
\hline & & & \\
\hline 1.04 & PM A & PM B & PM C \\
\hline PM A & 1 & 0.25 & 1.00 \\
PM B & 4.00 & 1 & 4.00 \\
PM C & 1.00 & 0.25 & 1 \\
\hline
\end{tabular}

Table 2, the score is 3 (judgment 'Weakly better'). So we should fill the cell with the value 3/1 (3.00);

(e) Cell PM B - PM B: in this case, we are comparing PM B with himself. Considering Table 2, the score is 1 (judgment 'Equal');

(f) Cell PM B - PM C: considering Table 1, PM B has a classification of 3 for the competence 1.01/knowledge and $\mathrm{PM} C$ has a classification of 5. So, the difference in the classifications is 2 (5-3), favourable to PM C. Considering Table 2, the score is 3 (judgment 'Weakly better'). So we should fill the cell with the value 1/3 (0.33);

(g) Cell PM C - PM A: considering Table 1, PM C has a classification of 5 for the competence 1.01/knowledge and PM A has a classification of 1 . So, the difference in the classifications is 4 (5-1), favourable to PM C. Considering Table 2, the score is 5 (judgment 'Definitely better'). So we should fill the cell with the value 5/1 (5.00);

(h) Cell PM C - PM B: considering Table 1, PM C has a classification of 5 for the competence 1.01/knowledge and PM B has a classification of 3. So, the difference in the classifications is 2 (5-3), favourable to PM C. Considering Table 2, the score is 3 (judgment 'Weakly better'). So we should fill the cell with the value 3/1 (3.00);

(i) Cell PM C - PM C: in this case, we are comparing PM B with himself. Considering Table 2, the score is 1 (judgment Equal).

The same process should be followed to create each pair-wise matrix, both for knowledge and experience criteria.

\subsection{Synthesis of the pair-wise comparison matrix}

After creating the pair-wise matrices it is necessary to synthesise them. Synthesising a pair-wise matrix is performed by dividing each element of the matrix by its columns total. Table 4 shows some of the synthesised matrices needed. Specifically, it presents the synthesised matrices for competences 1.01, 1.02, 1.03, 1.04 (for the knowledge criteria). It is important to note that, nevertheless the values in the pair-wise matrices were rounded (to two decimal places as shown in Table 3), the calculations of the synthesised matrices were made using a higher precision.

The matrix for competence 1.01 is obtained by:

(a) Cell PM A - PM A: dividing the value of the cell PM A - PM A of matrix 1.01 (on Table 3) by the sum of the column of PM A of matrix 1.01 (on Table 3); i.e. the result is equal to $1 /(1+3.00+5.00)=0.11111$;

(b) Cell PM A - PM B: dividing the value of the cell PM A - PM B of matrix 1.01 (on Table 3) by the sum of the column of PM B of matrix 1.01 (on Table 3); i.e. the result is equal to $0.33 /(0.33+1+3.00)=0.07692$;

(c) Cell PM A - PM C: dividing the value of the cell PM A - PM C of matrix 1.01 (on Table 3 ) by the sum of the column of PM C of matrix 1.01 (on Table 3); i.e. the result is equal to $0.20 /(0.20+0.33+1)=0.13043$;

(d) Cell PM B - PM A: dividing the value of the cell PM B - PM A of matrix 1.01 (on Table 3) by the sum of the column of PM A of matrix 1.01 (on Table 3); i.e. the result is equal to $3.00 /(1+3.00+5.00)=0.33333$;

(e) Cell PM B - PM B: dividing the value of the cell PM B - PM B of matrix 1.01 (on Table 3) by the sum of the column of PM B of matrix 1.01 (on Table 3); i.e. the result is equal to $1 /(0.33+1+3.00)=0.23077$;

(f) Cell PM B - PM C: dividing the value of the cell PM B - PM C of matrix 1.01 (on Table 3 ) by the sum of the column of PM C of matrix 1.01 (on Table 3); i.e. the result is equal to $0.33 /(0.20+0.33+1)=0.21739$;

(g) Cell PM C - PM A: dividing the value of the cell PM C - PM A of matrix 1.01 (on Table 3) by the sum of the column of PM A of matrix 1.01 (on Table 3 ); i.e. the result is equal to $5.00 /(1+3.00+5.00)=0.55556$; 
Table 4. Synthesised matrix for competences 1.01, 1.02, 1.03, 1.04 (knowledge criteria).

\begin{tabular}{|c|c|c|c|c|c|c|}
\hline 1.01 & PM A & PM B & $\mathrm{PM} \mathrm{C}$ & Priority & Weight sum & Max \\
\hline PM A & 0.111110 & 0.07692 & 0.130430 & 0.10616 & 0.31966 & 3.011200 \\
\hline PM B & 0.333330 & 0.23077 & 0.217390 & 0.26050 & 0.79008 & 3.032970 \\
\hline PM C & 0.555560 & 0.69231 & 0.652170 & 0.63335 & 1.94562 & 3.071970 \\
\hline CI: & 0.019357 & CR: & 0.033375 & & Total: & 3.038715 \\
\hline 1.02 & PM A & PM B & PM C & Priority & Weight sum & Max \\
\hline PM A & 0.14286 & 0.14286 & 0.14286 & 0.14286 & 0.42857 & 3.00000 \\
\hline PM B & 0.42857 & 0.42857 & 0.42857 & 0.42857 & 1.28571 & 3.00000 \\
\hline PM C & 0.42857 & 0.42857 & 0.42857 & 0.42857 & 1.28571 & 3.00000 \\
\hline CI: & 0 & CR: & 0 & & Total: & 3 \\
\hline 1.03 & PM A & PM B & $\mathrm{PM} \mathrm{C}$ & Priority & Weight sum & Max \\
\hline PM A & 0.142860 & 0.15789 & 0.111110 & 0.13729 & 0.41284 & 3.00710 \\
\hline PM B & 0.571430 & 0.63158 & 0.666670 & 0.62322 & 1.89084 & 3.03396 \\
\hline PM C & 0.285710 & 0.21053 & 0.222220 & 0.23949 & 0.72180 & 3.01395 \\
\hline CI: & 0.009169 & CR: & 0.015808 & & Total: & 3.018337 \\
\hline 1.04 & PM A & PM B & PM C & Priority & Weight sum & Max \\
\hline PM A & 0.16667 & 0.16667 & 0.16667 & 0.16667 & 0.50000 & 3.00000 \\
\hline PM B & 0.66667 & 0.66667 & 0.66667 & 0.66667 & 2.00000 & 3.00000 \\
\hline PM C & 0.16667 & 0.16667 & 0.16667 & 0.16667 & 0.50000 & 3.00000 \\
\hline CI: & 0 & CR: & 0 & & Total: & 3 \\
\hline
\end{tabular}

(h) Cell PM C - PM B: dividing the value of the cell PM C - PM B of matrix 1.01 (on Table 3) by the sum of the column of PM B of matrix 1.01 (on Table 3 ); i.e. the result is equal to $3.00 /(0.33+1+3.00)=0.69231$;

(i) Cell PM C - PM C: dividing the value of the cell PM C - PM C of matrix 1.01 (on Table 3 ) by the sum of the column of PM C of matrix 1.01 (on Table 3); i.e. the result is equal to $1 /(0.20+0.33+1)=0.65217$.

The same process should be followed to create each synthesised matrix, both for knowledge and experience.

\subsection{Compute the priority vector for the criterion}

Now we can compute the priority vector. The priority vector (column 'priority' of Table 4) is obtained by calculating the row averages. For matrix 1.01:

(a) Cell PM A (priority): $(0.11111+0.07682+0.13043) / 3=0.10616$

(b) Cell PM B (priority): $(0.33333+0.23077+0.21739) / 3=0.26050$

(c) Cell PM C (priority): $(0.55556+0.69231+0.65217) / 3=0.63335$

The same should be done for each matrix.

\subsection{Computation of the consistency ratio}

To compute the consistency ratio (CR) we have to follow several steps.

First we have to obtain the weight sum matrix. For matrix 1.01 it is calculated as follows:

$$
0.10616\left[\begin{array}{c}
1 \\
3.00 \\
5.00
\end{array}\right]+0.26050\left[\begin{array}{c}
0.33 \\
1 \\
3.00
\end{array}\right]+0.63335\left[\begin{array}{c}
0.20 \\
0.33 \\
1
\end{array}\right]=\left[\begin{array}{l}
0.31966 \\
0.79008 \\
1.94562
\end{array}\right]
$$


Table 5. Average random consistency (RI) (Saaty 1980, 1990).

\begin{tabular}{lcccccccccc}
\hline Size of matrix & 1 & 2 & 3 & 4 & 5 & 6 & 7 & 8 & 9 & 10 \\
\hline Random consistency & 0 & 0 & 0.58 & 0.9 & 1.12 & 1.24 & 1.32 & 1.41 & 1.45 & 1.49 \\
\hline
\end{tabular}

The result is listed in Table 4, column 'weight sum'.

Then, we have to divide all the elements of the weighted sum column by their respective priority vector element:

(a) Cell PM A (max): $0.31966 / 0.10616=3.01120$

(b) Cell PM B (max): $0.79008 / 0.26050=3.03297$

(c) Cell PM C (max): $1.94562 / 0.63335=3.07197$

These results are listed in column 'max' of Table 4.

We then compute the average of these values to obtain $\lambda$ max. For instance, for matrix 1.01:

$$
\lambda_{\max }=\frac{(3.01120+3.03297+3.07197)}{3}=3.0387147
$$

This average is needed to obtain the consistency index (CI). For matrix 1.01 the calculation will be:

$$
C I=\frac{\lambda_{\max }-n}{n-1}=\frac{3.0387147-3}{3-1}=0.0193573
$$

Before calculating the $\mathrm{CR}$, we must select the appropriate value of the random consistency ratio (RI). According to Table 5, for a matrix size of three elements, the RI is equal to 0.58 .

We calculate the CR, by dividing CI by RI. For matrix 1.01 the consistency ratio is calculated as follows:

$$
C R=\frac{C I}{R I}=\frac{0.0193573}{0.58}=0.0333747
$$

The same should be done for each matrix.

\subsection{Verification of the consistency of the pair-wise comparison matrix}

The next step consists of verifying the consistency of the pair-wise comparison matrix. The CR is acceptable if it does not exceed 0.10. If CR is higher than 0.10 , then the judgment matrix is inconsistent and judgments should be reviewed and improved (Saaty 1980; Al-Harbi 2001).

Consider as an example the matrix 1.01: this matrix has $\mathrm{CR}=0.0333746<0.10$, so we conclude that the judgments are acceptable.

As in the previous steps, the CR should be verified for each matrix.

\subsection{Computation of the final scores for each candidate}

Now we can compute the final scores for the candidates. Following the example of competences, we can also set

\begin{tabular}{|c|c|c|c|c|c|c|c|c|}
\hline \multirow[b]{2}{*}{ Competences } & \multirow[b]{2}{*}{ HK } & \multirow[b]{2}{*}{$\mathrm{HE}$} & \multicolumn{2}{|c|}{ Project Manager A } & \multicolumn{2}{|c|}{ Project Manager B } & \multicolumn{2}{|c|}{ Project Manager C } \\
\hline & & & Knowledge & Experience & Knowledge & Experience & Knowledge & Experience \\
\hline Technical competences & 0.33 & 0.33 & 0.37077 & 0.27900 & 0.36408 & 0.44971 & 0.26335 & 0.26982 \\
\hline Behavioural competences & 0.33 & 0.33 & 0.26207 & 0.42714 & 0.37606 & 0.23021 & 0.36515 & 0.34159 \\
\hline \multirow[t]{3}{*}{ Contextual competences } & 0.33 & 0.33 & 0.32983 & 0.36299 & 0.34343 & 0.23573 & 0.32674 & 0.40127 \\
\hline & & Total: & 0.31768 & 0.35281 & 0.35758 & 0.30216 & 0.31523 & 0.33419 \\
\hline & & Final: & \multicolumn{2}{|c|}{0.33525} & \multicolumn{2}{|c|}{0.32987} & \multicolumn{2}{|c|}{0.32471} \\
\hline
\end{tabular}
different weights for each type of competences. For convenience, we have set the same weight (0.33) for technical,

Table 6. Table with final scores of the candidates. 
behavioural and contextual competences. However, different projects certainly will have different needs, and the relative importance of the competence type can also be different. So, the weight should be defined accordingly. It is important to note that the weights should be set at the early stage of the selection process, to assure a fair selection process and to avoid bias.

In Table 6 we can find the summary of all calculations done. For each candidate, it presents the sum of scores of technical, behavioural and contextual competences (regarding knowledge and experience).

For instance, Project Manager A has a total score of 0.37077 regarding technical competences/knowledge. This score is the result of the weight sum of the priority columns of matrix 1.01 to 1.20 (knowledge):

$$
\text { PM A }(\text { tech. } / \text { know. })=0.10616 * 0.05+0.14286 * 0.05+0.13729 * 0.05+0.16667 * 0.05+\ldots=0.37077
$$

The total of knowledge is the weight sum of the total of each competence type. For instance, the total of knowledge for Project A is calculated as follows:

$$
\text { PM A }(\text { knowledge })=0.33 * 0.37077+0.33 * 0.26207+0.33 * 0.32983=0.31768
$$

The final score is obtained by the weight sum of the total score of knowledge and the total score of experience. By convenience, in this example, the experience and the knowledge criteria were considered as being of equal importance (0.50 each).

For instance, the final score for Project A is calculated as follows:

$$
\text { PM A (final score) }=0.50 * 0.31768+0.50 * 0.35281=0.33525
$$

We have now a ranking of candidates, according to their overall priorities. Considering only the knowledge competences, candidate PM B has a clear advantage, while considering only the experience competences it is candidate PM A who has advantage. With both type of competences, the best candidate is the PM A, with a score of 0.33525 .

\section{Conclusions}

Project management is not easy, because it entails the need of several and complementary competences and it is a permanent challenge for project managers. This is an activity that demands the best people in charge, because of the high amount of resources many times involved.

Selecting the most qualified project manager is a complex issue, because there are many issues to be considered and weighted, and it is necessary to assure that the chosen one have has a good balance in what is concerned with knowledge and experience.

In this paper we proposed the joint use of AHP (Analytic Hierarchy Process) and ICB (IPMA Competence Baseline), as a tool for selecting the most suitable managers for projects, taking into account multiple criteria. An example of the AHP implementation with ICB was explained. This tool could be of good support to decision-makers because it allows comparing the candidates for managing a project with a rich set of proven criteria. However, it is strongly recommended the use of a software tool to support all the process because of the higher level of computation needed. As future work we identify the opportunity of creating categories of projects with pre-defined hierarchy weights, to make the use of this tool easier for decision-makers.

\section{References}

Ahlemann, F., F. Teuteberg, and K. Vogelsang. 2009. "Project Management Standards - Diffusion and Application in Germany and Switzerland." International Journal of Project Management 27: 292-303.

Al-Harbi, K. M. 2001. "Application of the AHP in Project Management.” International Journal of Project Management 19: 19-27.

Bertolini, M., M. Braglia, and G. Carmignani. 2006. "Application of the AHP Methodology in Making a Proposal for a Public Work Contract." International Journal of Project Management 24: 422-430.

Carazo, A. F., T. Gómez, J. Molina, A. G. Hernández-Díaz, F. M. Guerrero, and R. Caballero. 2010. "Solving a Comprehensive Model for Multiobjective Project Portfolio Selection." Computers \& Operations Research 37: 630-639.

Chen, S. H., and H. T. Lee. 2007. "Performance Evaluation Model for Project Managers Using Managerial Practices." International Journal of Project Management 25: 543-551.

Crawford, L. H., J. B. Hobbs, and J. R. Turner. 2005. Project Categorization Systems: Aligning Capability with Strategy for Better Results. Newtown Square, PA: Project Management Institute. 
De Felice, F. D. 2012. "Research and Applications of AHP/ANP and MCDA for Decision Making in Manufacturing." International Journal of Production Research 50 (17): 4735-4737.

Fisher, E. 2010. "What Practitioners Consider to be the Skills and Behaviours of an Effective People Project Manager." International Journal of Project Management, JPMA-01272, 9p.

Gilan, S., M. H. Sebt, and V. Shahhosseini. 2012. "Research and Applications of AHP/ANP and MCDA For Decision Making in Manufacturing." Applied Soft Computing 12: 860-871.

Gutjahr, W. J., S. Katzensteiner, P. Reiter, C. Stummer, and M. Denk. 2010. "Multi-Objective Decision Analysis for Competence-Oriented Project Portfolio Selection.” European Journal of Operational Research 205: 670-679.

Ho, W., X. Xu, and P. K. Dey. 2010. "Multi-Criteria Decision Making Approaches for Supplier Evaluation and Selection: A Literature Review." European Journal of Operational Research 202: 16-24.

Hsiao, W.-H., T.-S. Chang, M.-S. Huang, and Y.-C. Chen. 2011. "Selection Criteria of Recruitment for Information Systems Employees: Using the Analytic Hierarchy Process (AHP) Method." African Journal of Business Management 5: 6201-6209.

IPMA. 2006. ICB - IPMA Competence Baseline Version 3.0. Nijkerk, The Netherlands: International Project Management Association.

Kelemenis, A., K. Ergazakis, and D. Askounis. 2011. "Support Managers' Selection Using an Extension of Fuzzy Topsis." Expert Systems with Applications 38: 2774-2782.

Kwak, Y. H., and F. T. Anbari. 2009. "Analyzing Project Management Research: Perspectives from Top Management Journals." International Journal of Project Management 27: 435-446.

Larrodé, E., J. M. Moreno-Jiménez, and M. V. Muerza. 2012. "An AHP-Multicriteria Suitability Evaluation of Technological Diversification in The Automotive Industry." International Journal of Production Research 50 (17): 4889-4907.

Müller, R., and R. Turner. 2007a. "Matching the Project Manager's Leadership Style to Project Type." International Journal of Project Management 25: 21-32.

Müller, R., and R. Turner. 2007b. "The Influence of Project Managers on Project Success Criteria and Project Success by Type of Project." European Management Journal 25 (4): 298-309.

Müller, R., and R. Turner. 2010. "Leadership Competency Profiles of Successful Project Managers." International Journal of Project Management 28: 437-448.

OGC. 2009. Managing Successful Projects With PRINCE2 ${ }^{\mathrm{TM}}$. Crown, UK: Office of Government Commerce.

Papke-Shields, K. E., C. Beise, and J. Quan. 2010. "Do Project Managers Practice What They Preach, and Does it Matter to Project Success?” International Journal of Project Management 28: 650-662.

Pinto, J. K., and D. P. Slevin. 1987. "Critical Factors in Successful Project Implementation." IEEE Transactions on Engineering Management 34 (1): 22-27.

PMI. 2008. A Guide to the Project Management Body of Knowledge (PMBoK ${ }^{\circledR}$ Guide). 4th ed. Newtown Square, PA: Project Management Institute.

Saaty, T. L. 1980. The Analytic Hierarchy Process. New York: McGraw-Hill.

Saaty, T. L. 1990. "How to Make a Decision: The Analytic Hierarchy Process." European Journal of Operational Research 48: 9-26.

Saaty, T. L., and L. G. Vargas. 2006. Decision Making with the Analytic Network Process: Economic, Political, Social and Technological Applications with Benefits, Opportunities, Costs and Risks. Pittsburg, PA: Springer.

Standish Group. 2010. Chaos Manifesto 2010. Boston, MA: The Standish Group.

Subramanian, N., and R. Ramanathan. 2012. "A Review of Applications of Analytic Hierarchy Process in Operations Management." International Journal of Production Economics 138: 215-241.

Varajão, J., J. Cardoso, D. Gonçalves, and J. B. Cruz. 2008. "Análise e Gestão de Projectos de Desenvolvimento de Software em Grandes Empresas Portuguesas.” Semana Informática 904: 10-12.

Wen-Yau, L. 2003. "The Analytic Hierarchy Process in Project Evaluation. An R\&D Case Study in Taiwan. Benchmarking." An International Journal 10 (5): 445-456.

Yang, I. T., and J.-S. Chou. 2011. "Multiobjective Optimization for Manpower Assignment in Consulting Engineering Firms." Applied Soft Computing 11: 1183-1190.

Zavadskas, E. K., P. Vainiunas, Z. Turskis, and J. Tamosaitiene. 2012. "Multiple Criteria Decision Support System for Assessment of Project Managers in Construction.” International Journal of Infornation Technology \& Decision Making 11 (2): 501-520. 